\title{
Assessment of Lead, Zinc and Cadmium Contamination in the Fruit of Palestinian Date Palm Cultivars Growing at Jericho Governorate
}

\author{
Walid M. Khalilia \\ Forensic Science Department, Al- Istiqlal University, PO. Box 10, Jericho, Palestine
}

\begin{abstract}
Phoenix dactylifera $\mathrm{L}$. fruits was studied to assess whether the fruits were safe for human consumption and evaluating the date fruit as a bio-monitor of heavy metals pollution in Palestine. Hence, current research explored the toxic heavy metals $(\mathrm{Pb}, \mathrm{Cd}$, and $\mathrm{Zn}$ ) levels in thirty-five date varieties collected from three locations (NARC, DH and ADS) of Jericho by applying anatomic absorption spectrometry. Mean values of heavy metals were calculated and expressed. the concentrations of heavy metals in date fruits flesh part were relatively higher as compared with the concentration of fruit washing residue. Heavy metals in the date palm fruits collected from NARC station (in the city center) reveals that the values are higher than ADS and DH stations (far away from the city center) due to higher human activity and higher vehicular traffic. Results of this study, reveals that most of studied heavy metals are within safe limit with respect to maximum allowable levels (MAL) in some date cultivars.
\end{abstract}

Keywords: Phoenix dactylifera L., Heavy metals, Lead, Zinc, Cadmium, Jericho.

DOI: $10.7176 / \mathrm{JBAH} / 10-2-02$

Publication date: January $31^{\text {st }} 2020$

\section{Introduction}

Date palm (Phoenix dactylifera L.) is the oldest cultivated fruit tree and it has a great socioeconomic and nutritional value. Date palm is broadly distributed in many regions of the world, including Asia, Africa, Arabian countries, and the Middle East (Pintaud et al., 2013). Date palm plantations in Palestine cover an area of 725 ha distributed in the regions of Jericho and the Jordan Valley (West Bank) and in the Gaza Strip (Abu-Qaoud, 2015). In the West Bank, there were 85,000 date palms spread over 600 ha, with a production capacity of 2,300 mt in 2012. In Gaza Strip the average date production in the last few years was 12,000 - 15,000 ton per year (Abd Rabou, 2017). Dates constitute $0.9 \%$ of total agricultural and cultivated with in the West Bank. Furthermore, Jericho governorate is considered the highest producer of soft dates, constituting $99 \%$ of total production in West Bank. The extremely high temperatures and the low relative humidity that prevail in this area during spring and summer provide the optimal conditions for growth and development of the date palm, as well as for maturation of the fruits (Palestinian Ministry of Agriculture, 2013).

The rapid increasing population in urban areas led to anthropogenic activities and fossil fuel combustion. Emissions from road traffic that uses fossil fuel, industry, agriculture, sewage sludge, and waste incineration are the chief sources of air pollution (Celik et al., 2005). Air pollution due to the heavy metals arises from these sources as well as from the dust storms (NRDC, 2005). Palestinian Territories, suffering from unstable political and security conditions, have limited environmental monitoring in most areas of the West Bank, leading to environmental neglect and degradation for many years. Wastewater produced in the Palestinian Territory is disposed of without any treatment in the agricultural environment. In addition, solid waste collection services in the West Bank do not cover all the population. the main sources of atmospheric pollution in the West Bank are industrial air emission, denes traffic, dust and particulate matter form stone quarries, and solid waste burning in open dumping sites (Swaileh, et al., 2004).

Human exposure to heavy metals $(\mathrm{Pb}, \mathrm{Cd}, \mathrm{Zn})$ has increased dramatically in recent years, especially in urban and industrial communities, where exposure to toxic chemicals and heavy metals cannot be avoided. Humans are often exposed to heavy metal contamination from dust that sticks to edible plants. The limits of toxic metals in the form of impurities depend on the nature of the sample and the contaminants or residues. The national limits for toxic metals contamination in various types of herbal products are different for each country and depend on the herb type and whether it is raw material or a finished product (Abualhasan, et. al., 2019). Heavy metals are considered to be dangerous and hazardous air pollutants to humans depending on their concentration in food. The presence of these contaminants in the fruit above the limit may lead to serious health risks to people who consume it (Banerjee, et al., 2010). There fore, the estimation of their levels in contaminated food is very important for the safety of human health.

The aims of this study was to assessment of heavy metals $(\mathrm{Pb}, \mathrm{Cd}$, and $\mathrm{Zn})$ contamination in the dust precipitated on the surface of fruits of date palm as well as in the fruit tissue after washing of Palestinian date palm cultivars growing at Jericho, in order to assess whether the fruits were safe for human consumption, protect 
the human health and evaluating the date fruit as a bio-monitor of heavy metals pollution in Jericho, Palestine.

\section{Materials and methods}

\subsection{Sampling}

Thirty five date palm fruit were collected from three identified sites in Jericho governorate $\left(31^{\circ} 52^{\prime} 16^{\prime \prime} \mathrm{N}\right.$ $35^{\circ} 26^{\prime} 39^{\prime \prime} \mathrm{E}$ ) during October 2019. samples were collected at Rutab stages (fully ripe) from 3 sites (Jericho Agriculture Experiment Station (NARC), Arab Development Society Station (ADS) and Deir Hijleh Station $(\mathrm{DH})$ ), and stored at $-20^{\circ} \mathrm{C}$. To determine the concentration of heavy metals $(\mathrm{Pb}, \mathrm{Cd}$ and $\mathrm{Zn})$ in the adhered dust on fruits, the dust was collected from each fruit sample collected from each site. Samples were weighted and washed with deionized distilled water (DDW) and the washing residues were collected in a beaker maintaining the final volume up to $150 \mathrm{~mL}$ using DDW. All beakers were kept on hot plate for complete dryness. The residue was kept for heavy metal estimation. After washing, all fruit samples were again kept for the estimation of heavy metal concentrations in the tissue of the fruit (Aldjain, et al. 2011).

One gram of the sample was placed in a $250 \mathrm{~mL}$ digestion tube and $10 \mathrm{~mL}$ of concentrated HNO3, and perchloric acid in the ratio 2:1 were added. The samples were heated for $45 \mathrm{~min}$ at $90{ }^{\circ} \mathrm{C}$.; later, the temperature was increased to $150{ }^{\circ} \mathrm{C}$. at which the samples were boiled for at least 2-3 h until a clear solution were obtained. Concentrated nitric acid and perchloric acid were added with hydrogen peroxide to the sample $(5 \mathrm{~mL}$ were added at least three times) and digestion continued until the volume were reduced to about $1 \mathrm{~mL}$. The interior walls of the tube were washed down with a little DDW and the tubes were swirled throughout the digestion to keep the wall clean and prevent the loss of the samples. After cooling, $5 \mathrm{~mL}$ of $1 \% \mathrm{HNO} 3$ were added to the sample. Thereafter, the solution was filtered using Whatman No. 42 filter paper and $<0.45 \mathrm{~lm}$ Millipore filter paper. The filtrate was then transferred to a $25 \mathrm{~mL}$ volumetric flask and volume were made up using distilled water. The content of heavy metals was determined by anatomic absorption spectrometer (Perkin-Elmer Model 300) following the method given in detail by Aldjain, et al., (2011). and the toxicity level were determined by comparing the present data with the permissible limit recommended by WHO.

\subsection{Statistical analysis}

The data were analyzed statistically with SPSS-17 statistical software (SPSS Inc., Chicago, IL, USA). Mean were statistically compared by Duncan's multiple range test at $\mathrm{P}<0.05 \%$ level. There were three replicates for each sample.

\section{Results}

The mean concentrations of heavy metals $(\mathrm{Pb}, \mathrm{Cd}$ and $\mathrm{Zn})$ in the washing residues and flesh part of date palm fruits from different sites are studied and presented in figure 1 and table 1 . There were significant variations $(\mathrm{P}<$ 0.05 ) in concentrations of heavy metals in fruits washing residue and fruit flesh tissues according to sample site. In case of $\mathrm{Cd}, \mathrm{Zn}$ and $\mathrm{Pb}$ the concentrations in date fruits flesh part were relatively higher as compared with the concentration of fruit washing residue. On the contrary, the concentrations of $\mathrm{Cd}, \mathrm{Pb}$ and $\mathrm{Zn}$ were significantly higher in fruits from NARC station as compared with ADS and DH stations. In almost all the treatments the metal concentrations in fruits were within the standards proposed by different organizations, e.g., WHO/FAO (2011), European Union (2006) and Indian standards (Awashthi, 2000).

Figure 1 reveal that $\mathrm{Zn}$ was the most abundant between the studied three elements, and it was significantly high in all three studied sites. Zn concentration in flesh tissue was higher than the concentration in fruits washing residues. On the other hand, $\mathrm{Cd}$ concentrations were the least in the three studied sites. 


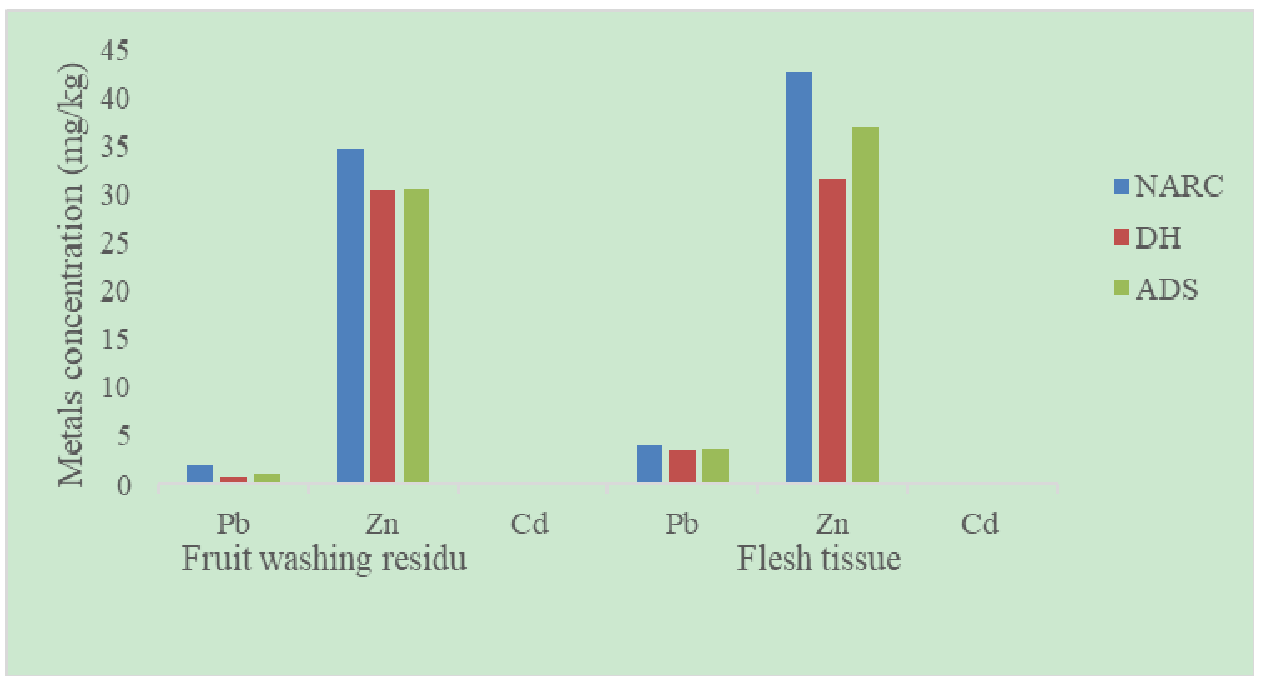

Figure 1: Lead, Zinc and Cadmium concentration ( $\mathrm{mg} / \mathrm{kg}$ dry weight) in date palm washing residues and tissue of flesh fruit growing in the three studied sites at Jericho.

In our findings, heavy metal concentration in the flesh tissue are higher than in the washing residues from fruits (Table 1). Zn was the highest value $42.674 \mathrm{mg} / \mathrm{kg}^{-1}$ dry weight in NARC station. The highest lead concentration in date palm fruits was found in the NARC station $\left(3.9146 \mathrm{mg} / \mathrm{kg}^{-1}\right.$ dry weight) as compared to the $\mathrm{DH}$ and ADS stations $\left(0.829\right.$ and $1.0967 \mathrm{mg} / \mathrm{kg}^{-1}$ dry weight) respectively. The least value was for Cd i.e., $0.01433 \mathrm{mg} / \mathrm{kg}^{-1}$ dry weight (Table 1).

Data in Table 1 reveal that in NARC station, the extractable mean values of heavy metals $(\mathrm{Pb}, \mathrm{Zn}$ and $\mathrm{Cd})$ in date palm washing residues were 1.9931, 34.915 and $0.02485 \mathrm{mg} \mathrm{kg-}^{-}$, in DH station $0.829,30.394$ and $0.0178 \mathrm{mg} \mathrm{kg-}{ }^{1}$, while in ADS station 1.0967, 30.532 and $0.01433 \mathrm{mg} \mathrm{kg-}^{-1}$, respectively.

Table 1. Average concentration of all samples for each studied site for Lead, Zinc and Cadmium (mg/kg dry weight) in date palm washing residues and tissue of fruit growing at Jericho.

\begin{tabular}{lrrrrrl} 
& \multicolumn{3}{c}{ Washing residues } & \multicolumn{3}{c}{ Fruit flesh } \\
\cline { 2 - 7 } & \multicolumn{1}{c}{$\mathbf{P b}$} & $\mathbf{Z n}$ & \multicolumn{1}{c}{ Cd } & \multicolumn{1}{c}{ Pb } & Zn & Cd \\
NARC & 1.9931 & 34.915 & 0.02485 & 3.9146 & 42.674 & 0.04 \\
DH & 0.829 & 30.394 & 0.0178 & 3.438 & 31.539 & 0.02 \\
ADS & 1.0967 & 30.532 & 0.01433 & 3.645 & 36.987 & 0.02
\end{tabular}

Results presented in Table 2 for Lead, Zinc and Cadmium average concentrations in date palm washing residues and tissue of fruit growing in NARC, ADS and DH stations revealed significant variations $(\mathrm{P}<0.05)$ between cultivars. So, out of thirty-five dates cultivars studied, the average concentration of the three heavy metals in fruit flesh and washing residues for the improved and introduced cultivars Maijhool, Deglet noor, Barhi and Hayani were the highest concentrations. For $\mathrm{Zn}$ concentration in fruit flesh tissue for Deglet noor was the highest value i.e., $51.12 \mathrm{mg} / \mathrm{kg}^{-1}$ dry weight from NARC station. For $\mathrm{Pb}$ the highest concentration in fruit washing residue and in flesh tissue was 3.51 and $5.23 \mathrm{mg} / \mathrm{kg}^{-1}$ dry weight for Maijhool and Deglet noor cultivars respectively from NARC station. Baladil the least $\mathrm{Pb}$ concentration in fruit flesh i.e., $2.13 \mathrm{mg} / \mathrm{kg}^{-1}$ and 0.54 $\mathrm{mg} / \mathrm{kg}^{-1}$ in fruit washing residue of Baladi9 cultivar from DH station. Cadmium concentration was very low and not detectable (ND) in many cultivars. The concentration of heavy metals $(\mathrm{Cd}, \mathrm{Zn}$ and $\mathrm{Pb})$ are in the normal range in date palm fruit flesh parts, except concentration of lead in Maijhool and Deglet noor samples from NARC station which were higher than the safe limits (Table 2). 
Table 2. Concentrations of Lead, Zinc and Cadmium ( $\mathrm{mg} / \mathrm{kg}$ dry weight) in date palm washing residues and tissue of fruit growing in different locations of Jericho.

\begin{tabular}{|c|c|c|c|c|c|c|c|c|}
\hline \multirow[b]{2}{*}{ Site } & \multirow[b]{2}{*}{ Cultivar } & \multirow[b]{2}{*}{ Sample \# } & \multicolumn{3}{|c|}{ Washing residues } & \multicolumn{3}{|c|}{ Fruit flesh } \\
\hline & & & $\mathbf{P b}$ & Zn & Cd & $\mathbf{P b}$ & $\mathbf{Z n}$ & Cd \\
\hline \multirow{13}{*}{$N A R C$} & Baladi 1 & 1. & 0.65 & 31.25 & 0.013 & 2.13 & 32.15 & 0.021 \\
\hline & Baladi 2 & 2. & 0.87 & 32.36 & 0.019 & 2.5 & 45.33 & 0.042 \\
\hline & Baladi 3 & 3. & 1.23 & 25.41 & 0.021 & 3.75 & 36.12 & 0.019 \\
\hline & Baladi 4 & 4. & 1.03 & 28.08 & 0.03 & 3.27 & 30.32 & 0.033 \\
\hline & Baladi 5 & 5. & 0.56 & 36.16 & 0.012 & 2.55 & 46.56 & 0.014 \\
\hline & Baladi 6 & 6. & 1.12 & 25.98 & 0.022 & 4.25 & 29.85 & 0.047 \\
\hline & Maijhool & 7. & 3.51 & 48.12 & 0.035 & 5.13 & 50.84 & 0.062 \\
\hline & Barhi & 8. & 3.17 & 39.25 & 0.021 & 4.82 & 48.98 & 0.043 \\
\hline & Deglet noor & 9. & 3.09 & 48.16 & 0.041 & 5.23 & 51.12 & 0.058 \\
\hline & Hijazi & 10. & 2.55 & 30.51 & 0.033 & 4.25 & 45.26 & 0.041 \\
\hline & Zhedi & 11. & 2.89 & 39.25 & 0.022 & 4.31 & 44.89 & 0.048 \\
\hline & Khadrawy & 12. & 2.36 & 36.24 & 0.023 & 3.87 & 43.78 & 0.037 \\
\hline & Hayani & 13. & 2.88 & 33.12 & 0.031 & 4.83 & 49.56 & 0.049 \\
\hline \multirow{10}{*}{ DH } & Baladi 7 & 14. & 0.56 & 38.43 & 0.018 & 3.12 & 31.58 & 0.021 \\
\hline & Baladi 8 & 15. & 0.63 & 34.91 & 0.011 & 3.56 & 31.48 & 0.024 \\
\hline & Baladi 9 & 16. & 0.54 & 28.12 & ND & 2.15 & 29.89 & ND \\
\hline & Baladi 10 & 17. & 0.66 & 28.25 & ND & 2.89 & 30.54 & 0.011 \\
\hline & Baladi 11 & 18. & 0.64 & 30.24 & 0.011 & 3.1 & 29.81 & 0.034 \\
\hline & Baladi 12 & 19. & 0.76 & 24.16 & ND & 3.51 & 28.78 & 0.022 \\
\hline & Baladi 13 & 20. & 0.82 & 21.24 & 0.018 & 3.82 & 30.71 & ND \\
\hline & Maijhool & 21. & 2.46 & 43.2 & 0.031 & 4.88 & 44.26 & 0.032 \\
\hline & Baladi 14 & 22. & 0.59 & 26.09 & ND & 3.16 & 28.56 & 0.011 \\
\hline & Baladi 15 & 23. & 0.63 & 29.3 & ND & 4.19 & 29.78 & ND \\
\hline \multirow{12}{*}{$A D S$} & Baladi 16 & 24. & 1.13 & 26.08 & 0.012 & 3.59 & 36.58 & 0.032 \\
\hline & Baladi 17 & 25. & 0.81 & 24.25 & 0.013 & 3.43 & 34.46 & 0.036 \\
\hline & Baladi 18 & 26. & 0.77 & 29.79 & 0.011 & 4.12 & 37.09 & 0.037 \\
\hline & Baladi 19 & 27. & 1.32 & 31.08 & ND & 3.84 & 35.09 & 0.021 \\
\hline & Baladi 20 & 28. & 0.92 & 33.06 & 0.019 & 3.69 & 38.61 & ND \\
\hline & Baladi 21 & 29. & 1.33 & 35.5 & ND & 3.83 & 40.16 & 0.012 \\
\hline & Baladi 22 & 30. & 1.45 & 29.92 & 0.017 & 3.79 & 35.68 & 0.023 \\
\hline & Baladi 23 & 31. & 1.32 & 30.38 & 0.009 & 3.19 & 39.09 & 0.017 \\
\hline & Baladi 24 & 32. & 0.97 & 27.15 & 0.014 & 3.49 & 34.9 & 0.026 \\
\hline & Baladi 25 & 33. & 0.89 & 33.04 & 0.016 & 3.2 & 37.17 & 0.02 \\
\hline & Baladi 26 & 34. & 1.22 & 31.51 & ND & 3.88 & 39.81 & 0.011 \\
\hline & Baladi 27 & 35. & 1.03 & 34.62 & 0.018 & 3.69 & 35.2 & 0.014 \\
\hline \multicolumn{3}{|c|}{ *MAL } & 5 & 60 & 0.2 & 5 & 60 & 0.2 \\
\hline
\end{tabular}

* Standards proposed by different organizations, e.g., means maximum allowable limit (mg/kg) prescribed by WHO/FAO (2011), European Union (2006) and Indian standards (Awashthi, 2000); ND: Not Detected; Each value is a mean of three replicates.

Results presented in Figure 2 reveal that samples 1 to 13 from NARC station recorded the highest Zn concentrations for fruit flesh and washing residues. Whereas samples 14 to 23 from DH station revealed the least values except sample number 21 (Maijhool) recorded high concentration of $\mathrm{Zn}$. In general, Zn concentration in fruit flesh tissues and washing residues for the most studied samples were within the international safe limits $(\leq$ $60)$. 


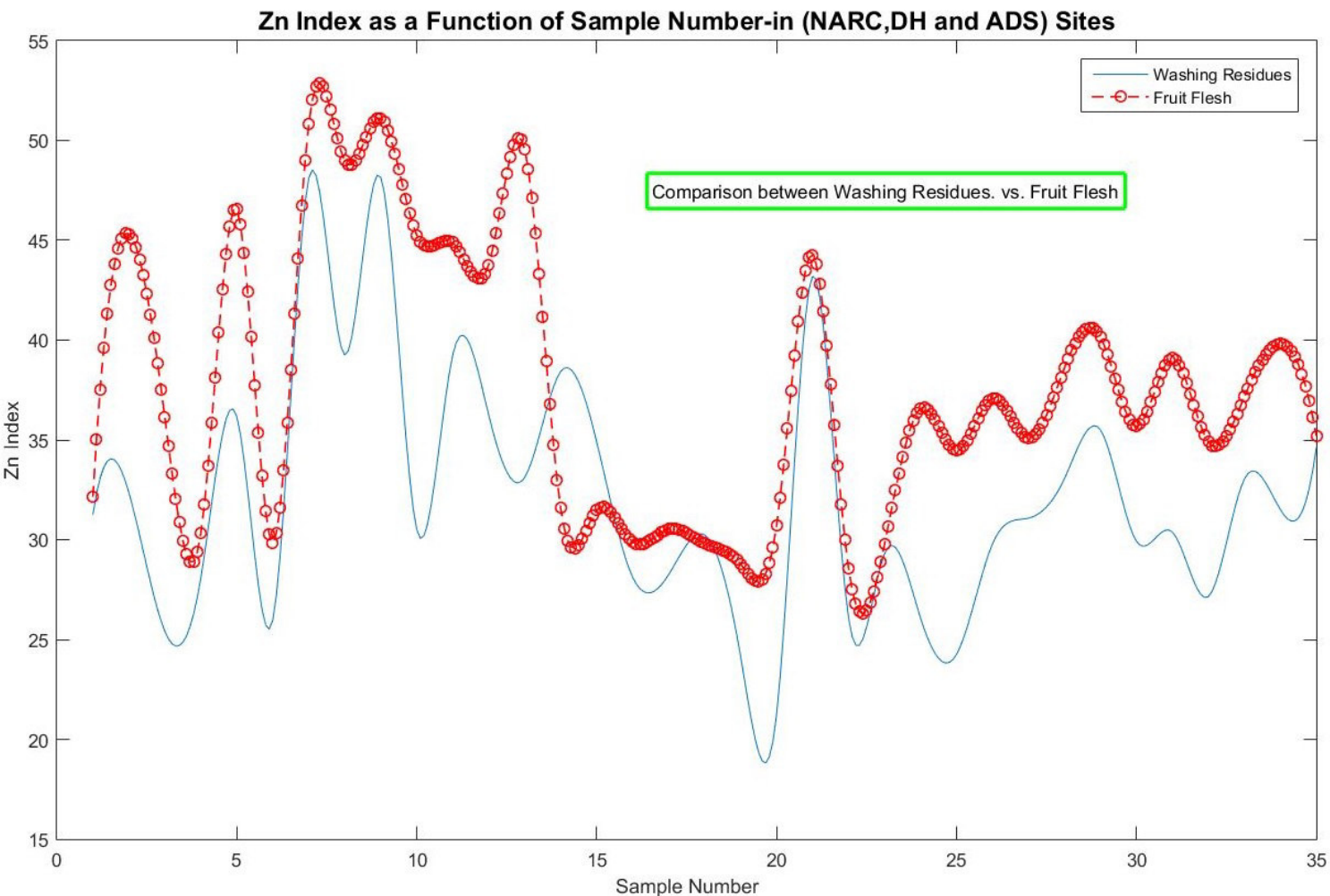

Figure 2. Zinc concentrations in date palm fruit growing in NARC, DH and ADS stations at Jericho.

Results presented in Figure 3 for Lead concentration in date palm fruit flesh and washing residues in the three studied sites, reveal that the samples from 1 to 13 from NARC station recorded the highest $\mathrm{Pb}$ concentration as compared to the $\mathrm{DH}$ and ADS stations. Whereas the least samples of $\mathrm{Pb}$ concentration was recorded for samples 16 and 17 (Baladi9 and Baladi10) from DH station. In general, Pb concentration in fruit flesh tissues and washing residues for all studied samples were within the international safe limits $(\leq 5)$.

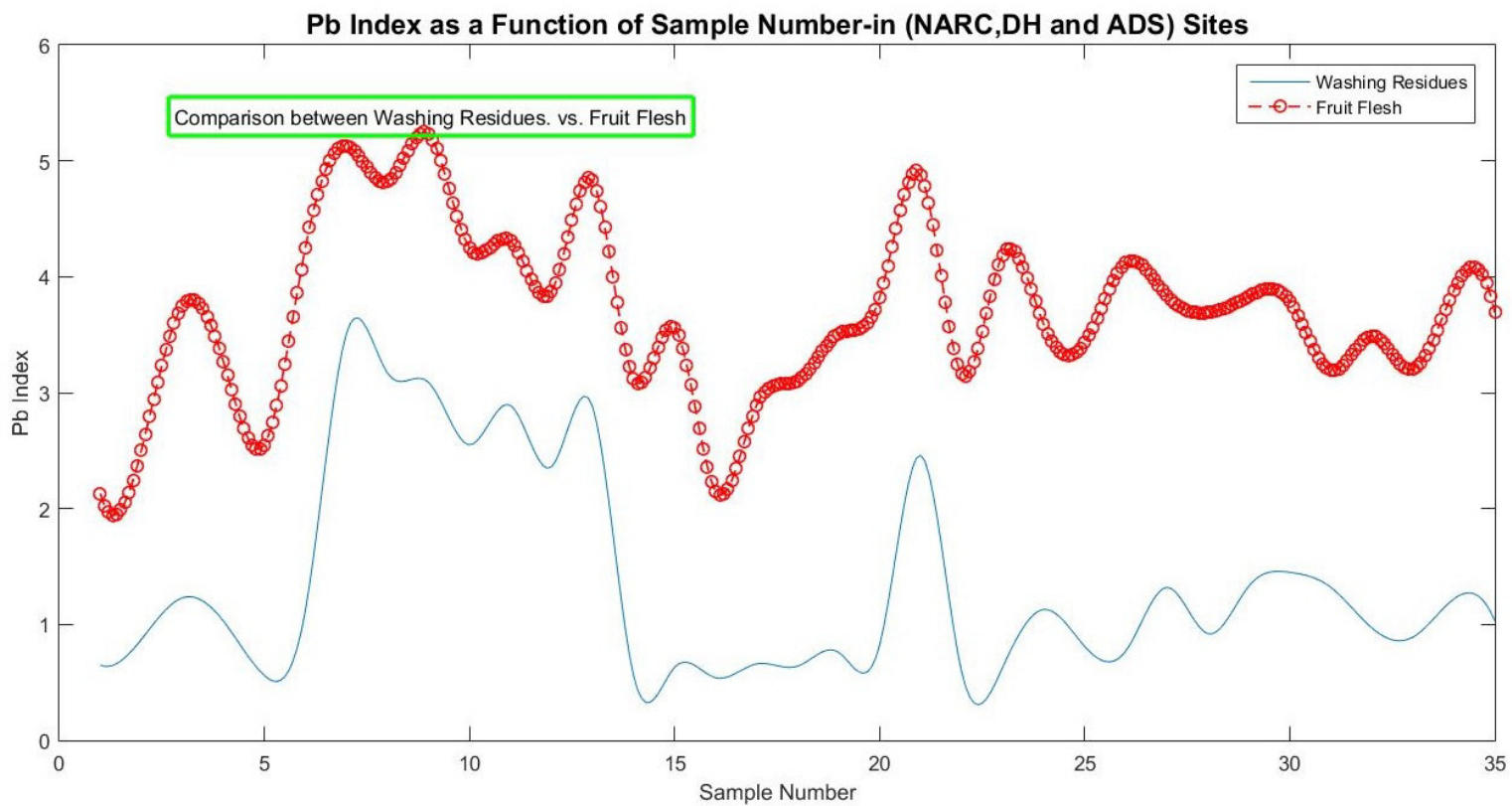

Figure 3. Lead concentrations in date palm fruit growing in NARC, DH and ADS stations at Jericho.

Figure 4 reveal that $\mathrm{Cd}$ concentration in fruit flesh and washing residues for the improved and introduced cultivars Maijhool, Deglet noor, Barhi and Hayani recorded the maximum values compared with local strains (Baladi). In general, $\mathrm{Pb}$ concentration in fruit flesh tissues and washing residues for all studied samples were within the international safe limits $(\leq 0.2)$. 


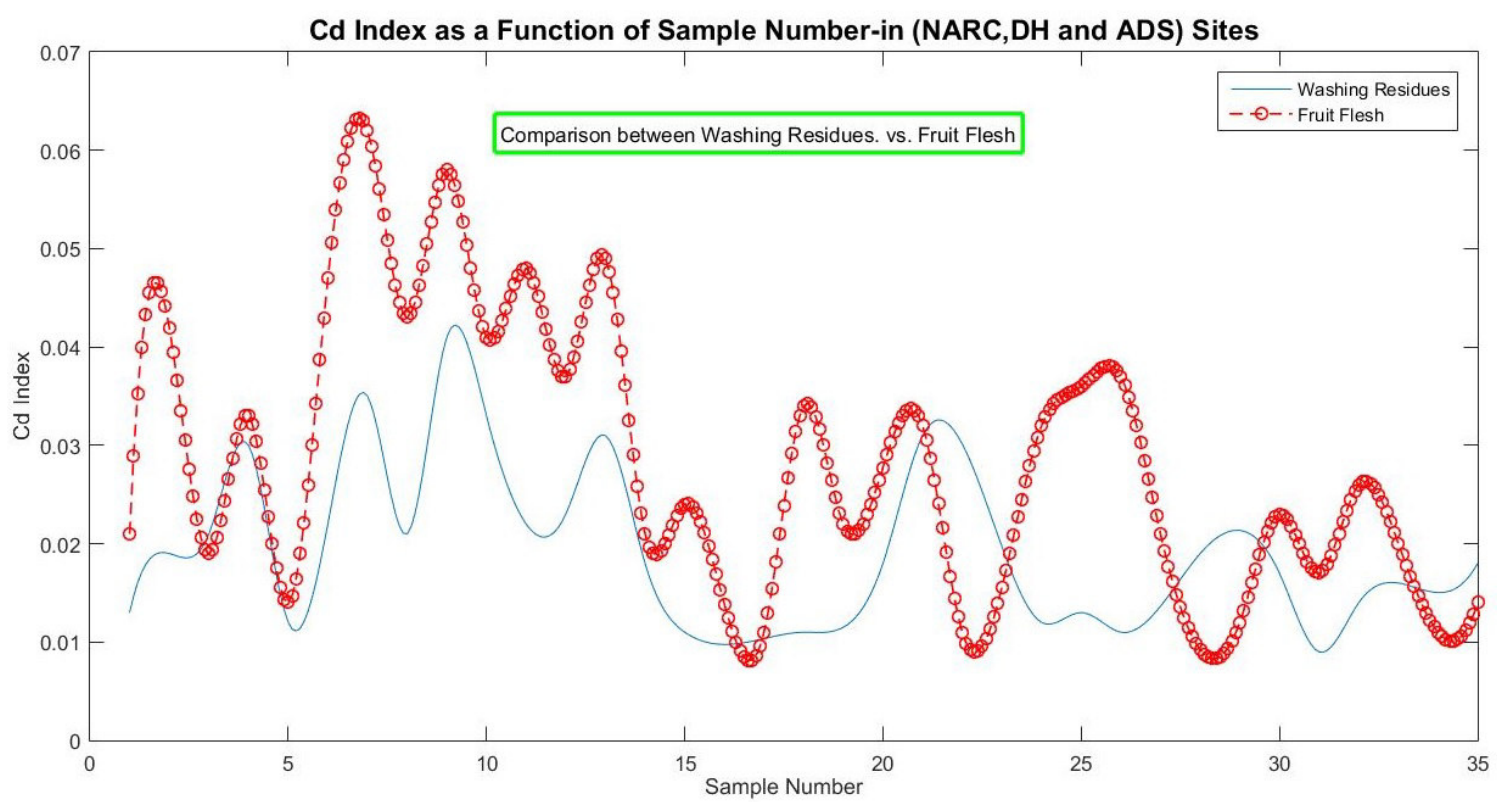

Figure 4. Cadmium concentrations in date palm fruit growing in NARC, DH and ADS stations at Jericho.

\section{Discussion}

In view of the importance of protection of the population in Palestine from being exposed to heavy metal hazard. This study important for obtaining a representative data of heavy metals concentration levels in date palm fruits in Palestine. Fruits are the most important part of the plants for human consumption and concentrations of all elements should be within the range of safety standards. Conclusively, metals uptake by plants depends upon species of plants, which introduces these hazards in food chain causing health threats (Antonious and Kochher, 2009). Yuan, et al. (2016) reviewed that, heavy metals contamination has become a major environmental problem. Numerous investigations have revealed an association between heavy metal exposure and the incidence and mortality of cancer. From our results, the mean concentrations of $\mathrm{Pb}, \mathrm{Cd}$ and $\mathrm{Zn}$ in the washing residues and flesh part of date palm fruits from different sites are studied. There was a significant variation $(\mathrm{P}<0.05)$ in concentrations of heavy metals in fruits washing residue and fruit flesh tissues according to sample site and kind of heavy metals (Shin, et al., 2013). The highest concentration was in NARC station in the city center Jericho. While less concentrations of $\mathrm{Pb}, \mathrm{Cd}$ and $\mathrm{Zn}$ in fruits from $\mathrm{ADS}$ and $\mathrm{DH}$ stations was detected in these two stations which are far away from the city center of Jericho. Heavy metals in the date palm fruits reveals that the values in the city center are higher than other sites due to higher human activity and higher vehicular traffic. A similar finding is reported by Tam et al. (1987) from Hongkong who found a significant correlation between traffic density and $\mathrm{Pb}$ and $\mathrm{Zn}$ concentrations. Another study about assessment of heavy metal contamination in roadside surface soil and vegetation from the West Bank conducted by Swaileh, et al. (2004), indicate that roadside contamination with heavy metals was obvious by the significant negative correlations between concentrations of metals in soil and plant samples and distance from road edge. Previous studies had reported some high levels of heavy metals concentration in other places surrounding Jericho (Abualhasan, et al., 2019).

Results from this study, demonstrated different contamination levels of lead, zinc and cadmium in different date palm fruits cultivars collected from various locations in Jericho the city of date palm in Palestine. From other study by Sultana, et al. (2017) reported that heavy metals in vegetables and fruits varied with vegetable and fruit species as well as metal types. Lead concentration may be attributed to various causes where automobile contribute to a greater extent followed by the use of lead-based pesticides in crop protection. The deposit of lead on edible tissues of crops also depends upon air pollution, air dust, distance from the roads side as well as traffic loads (Salama et al., 2019). Hussain et al. analyzed dates imported into Kuwait and found that dates collected from different location were differing in $\mathrm{Pb}$ contents and some of the samples were exceeding the MAL values. Radwan and Salama (2006) during market basket survey for some heavy metals in Egyptian fruits and vegetables found that $\mathrm{Pb}$ contents in dates were $0.22 \mathrm{mg} / \mathrm{kg}$ and even higher $\mathrm{Pb}$ contents were observed in strawberries, peach, and melon. Cadmium concentration in all samples grown in the three different study sites was within the normal range. Whereas its concentration differs according to the location of date palm trees. Another previous study conducted at Riyadh by Aldjain, et al. (2011), date palm fruits collected from different sites showed the presence of significant amounts of the $\mathrm{Pb}$ and $\mathrm{Cd}$. The concentration of $\mathrm{Pb}$ in the dust and fruit tissue increased with increasing anthropogenic sources. The change in the level of cadmium that occurs between samples collected from the three studied sites may be due to the ability of plant absorption that depends on the 
content of heavy minerals in the soil and genetic makeup of the plant. Cadmium can result in diseases of kidney, lungs and also can lead to skeleton problems as it is related with cancerous risk as compared to lead which is non-cancer risk factor (Salama et al., 2019). Current study elucidated low level of $\mathrm{Cd}$ as compared to $\mathrm{Pb}$ revealing uptake of heavy metals owing to plant ability to accumulate them (Ahmed and Al-Swaidan. 1993). Cadmium can be deposited in the edible tissues due to agricultural practices as Cd can via usage of polluted sewage water, type of soil, and the application of phosphate fertilizers. Zinc has been described as an essential plant nutrient element. Plant species show differential behavior as regards the Zn content (Yilmaz, et al., 2006). In our results $\mathrm{Zn}$ mean concentration in fruit flesh tissue varied between $51.12-28.56 \mathrm{mg} / \mathrm{kg}$ dry weight and the values of $\mathrm{Zn}$ in fruit washing residues varies between $21.24-48.16 \mathrm{mg} / \mathrm{kg}$. Similar results were obtained by Shomar (2006) for all metals. In the soils $\mathrm{Zn}$ levels in general were higher than $\mathrm{Cd}$ and $\mathrm{Pb}$ except for the $\mathrm{Pb}$ in urban roadside soils (Yilmaz, et al., 2006). Therefore, it can be suggested that Zn concentration in all plants grown in the study areas was within the normal range.

\section{Conclusion}

In conclusion, the results indicate that the concentration of heavy metals within the safe limits in the washing residues and flesh part of date palm fruits in Jericho region. The concentration of heavy metals in dust and the tissue of date palm fruits increased with increasing anthropogenic activities. There is probability that fruits of date palm may be used as bio-indicator for heavy metals pollution and may be recommended for its consumption after washing as human health safety measurement. Previous investigation should be extended to include areas and places in the Palestinian territory that are not investigated before in order to have sufficient data needed to establish a complete heavy metals distribution map for the Palestinian territories.

\section{References}

Abd Rabou, A. F. N. (2017). The current status of the date palm (Phoenix dactylifera) and its uses in the Gaza Strip, Palestine. Biodiversitas, Journal of Biological Diversity, 18(3). https://doi.org/10.13057/biodiv/d180324

Abualhasan, M., Jaradat, N., Sawaftah, Z., Mohsen, H., Najjar, D., \& Zareer, W. (2019). Evaluation of Heavy Metals and Microbiological Contamination of Selected herbals from Palestine. Open Life Sciences, 14(1), 448-453. https://doi.org/10.1515/biol-2019-0050

Abu-Qaoud, H., (2015). Date Palm Status and Perspective in Palestine. In Date Palm Genetic Resources and Utilization. Jameel M. Al-Khayri, Shri Mohan Jain, and Dennis V. Johnson, eds. Pp. 423-439. Springer Netherlands. http://link.springer.com/chapter/10.1007/978-94-017-9707-8_13, accessed March 30, 2017.

Ahmed, K. O.; Al-Swaidan, H. M., (1993). Lead and Cadmium in Urban Dust of Riyadh, Saudi Arabia. Sci. Total Environ., 136(1-2), 205-210. DOI: 10.1016/0048-9697(93)90308-S.

Aldjain, Ibrahim M., Mohamed H. Al-Whaibi, Salim S. Al-Showiman, and Manzer H. Siddiqui, (2011). Determination of Heavy Metals in the Fruit of Date Palm Growing at Different Locations of Riyadh. Saudi Journal of Biological Sciences 18(2): 175-180.

Antonious, G. F.; Kochher, T. S., (2009) Mobility of Heavy Metals Fromsoil into Hot Pepper Fruits: A Field Study. Bull. Environ. Contam.Toxicol., 82(1), 59-63. DOI: 10.1007/s00128-008-9512-8.

Awashthi, S.K., (2000). Prevention of Food Adulteration Act no 37 of 1954. Central and State Rules as Amended for 1999, Ashoka Law House, New Delhi.

Banerjee, Debopam, Prabir Kuila, Anindita Ganguly, and Lalitagauri Ray (2010), Market Basket Survey for Chromium, Copper, Lead and Cadmium in Some Vegetables from Different Shopping Malls in Kolkata, India. Electronic Journal of Environmental, Agricultural and Food Chemistry 9(7): 1190-1195.

Celik, A., Kartal, A., Akdogan, A., Kaska, Y., (2005). Determination of heavy metal pollution in Denizli (Turkey) by using Robinio pseudoacacia L. Environ. Int. 31 (1), 105-112.

EU., (2006). Commission regulation (EC) No. 1881/2006 of 19 December 2006 setting maximum levels for certain contaminants in foodstuffs. Official J. Euro. Union, L364/5.

Husain, A.; Baroon, Z.; AI-khalafawi, M.; Ati, T. A. I.; Sawaya, W., (1995). Toxic Metals in Imported Fruits and Vegetables Marketed in Kuwait. Environ. Int., 21(6), 803-805. DOI: 10.1016/0160-4120(95)00093-6. NRDC, (2005). Toxic Metals in New Orleans Air. Available at: $<$ http://www.nrdc.org/health/effects/katrinadata/metals.asp $>$ (retrieved on 12/08/2010)

Palestinian Ministry of Agriculture (2013). Cultivated area of surveyed crops 2012/2013. Unpublished data.

Pintaud, J.-.C., Ludeña, B., Aberlenc-Bertossi, F., Zehdi, S., Gros-Balthazard, M., Ivorra, S., Terral, J.-.F., Newton, C., Tengberg, M., Abdoulkader, S., Daher, A., Nabil, M., Saro Hernández, I., González-Pérez, M.A., Sosa, P., Santoni, S., Moussouni, S., Si-Dehbi, F. and Bouguedoura, N. (2013). Biogeography of the date palm (phoenix dactylifera L., arecaceae): insights on the origin and on the structure of modern diversity. Acta Hortic. 994, 19-38. DOI: 10.17660/ActaHortic.2013.994.1

Radwan, M. A.; Salama, A. K., (2006). Market Basket Survey for Some Heavy Metals in Egyptian Fruits and 
Vegetables. Food Chem. Toxicol., 44, 1273-1278. DOI: 10.1016/j.fct.2006.06.020.

Salama, K. F., Randhawa, M. A., Al Mulla, A. A., \& Labib, O. A. (2019). Heavy metals in some date palm fruit cultivars in Saudi Arabia and their health risk assessment. International Journal of Food Properties, 22(1), 1684-1692. https://doi.org/10.1080/10942912.2019.1671453

Shin, M.-Y., Cho, Y.-E., Park, C., Sohn, H.-Y., Lim, J.-H., \& Kwun, I.-S. (2013). The Contents of Heavy Metals $(\mathrm{Cd}, \mathrm{Cr}, \mathrm{As}, \mathrm{Pb}, \mathrm{Ni}$, and $\mathrm{Sn})$ in the Selected Commercial Yam Powder Products in South Korea. Preventive Nutrition and Food Science, 18(4), 249-255. https://doi.org/10.3746/pnf.2013.18.4.249

Shomar, B., (2006). Inorganic and Organic Environmental Geochemical Issues of the Gaza Strip-Palestine. Ph.D. Environmental Geochemistry. University of Heidelberg, Germany.

Sultana, Mahfuza S., Rana, S., Yamazaki, S., Aono, T. and Yoshida, S. (2017). Health Risk Assessment for Carcinogenic and Non-Carcinogenic Heavy Metal Exposures from Vegetables and Fruits of Bangladesh. Cogent Environmental Science 3(1): 1291107.

Swaileh, K. M., Hussein, R. M. and Abu-Elhaj S., (2004). Assessment of Heavy Metal Contamination in Roadside Surface Soil and Vegetation from the West Bank. Archives of Environmental Contamination and Toxicology 47(1): 23-30. https://doi.org/10.1007/s00244-003-3045-2

Tam, N.F.Y., Liu, W.K. Wang, M.H. and Wong. Y.S., (1987). Heavy metal pollution in roadside, urban parks and gardens in Hongkong. Sci. Total Environ., 59: 325-328.

WHO/FAO. Joint FAO/WHO (2011). Food Standards Programme Codex Committee on Contaminants in Foods. The Neth. 2011, 21-25(march).

Yilmaz, R., Trakya U., Sakcali, S., Marmara U., Yarci, C., Marmara U., Aksoy, A., Ercites U., \& Ozturk, M., Ege U. (2006). Use of Aesculus hippocastanum L. as a biomonitor of heavy metal pollution. Pakistan Journal of Botany (Pakistan). http://agris.fao.org/agrissearch/search.do?recordID=PK2008000033

Yuan, W., Ning Y., and Xiangkai L., (2016). Advances in Understanding How Heavy Metal Pollution Triggers Gastric Cancer. Research article. BioMed Research International. https://www.hindawi.com/journals/bmri/2016/7825432/, accessed September 8, 2018. 